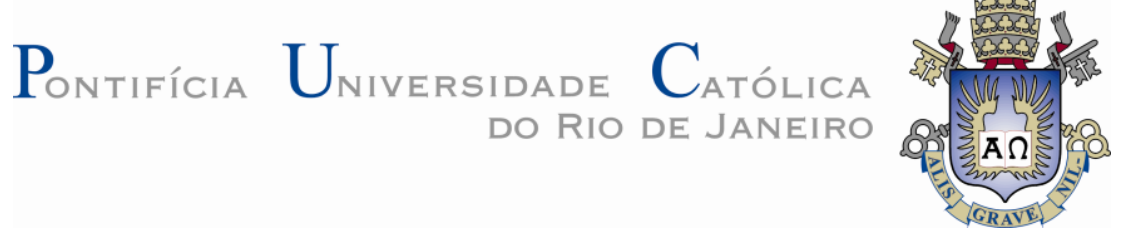

Renato Nunes Teixeira

Development of High Temperature Comparison Artefacts for Radiation Thermometry

Tese de Doutorado

Thesis presented to the Programa de PósGraduação em Engenharia Mecânica, PUC-Rio as partial fulfillment of the requirements for the degree of Doutor em Engenharia Mecânica.

Advisor: Prof. Alcir de Faro Orlando

Co-Advisor: Prof. Graham Machin

Rio de Janeiro

July 2013 


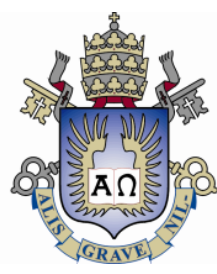

Renato Nunes Teixeira

\section{Development of High Temperature Comparison Artefacts for Radiation Thermometry}

Thesis presented to the Programa de PósGraduação em Engenharia Mecânica da PUCRio, as partial fulfillment of the requirements for the degree of Doutor.

Prof. Alcir de Faro Orlando

Advisor

Departamento de Engenharia Mecânica - PUC-Rio

Prof. Graham Machin

Co-Advisor

NPL - UK

Prof. José Alberto dos Reis Parise

Departamento de Engenharia Mecânica - PUC-Rio

Prof. Luis Fernando Alzuguir Azevedo Departamento de Engenharia Mecânica - PUC-Rio

Prof. Maurício Nogueira Frota

Programa de Pós-Graduação em Metrologia - PUC-Rio

Prof. José Ricardo Sodré

PUC-Minas

Prof. Hans Peter Henrik Grieneisen Inmetro

Prof. José Eugênio Leal Sectoral Coordinator of the Centro

Técnico Científico - PUC-Rio

Rio de Janeiro, July $19^{\text {th }} 2013$ 
All rights reserved.

Renato Nunes Teixeira

The author is graduated in Mechanical Engineering from Universidade Federal Fluminense in 1988, he obtained the degree of Mestre at PUC-Rio in 1992. He is an employee of the Instituto Nacional de Metrologia, Tecnologia e Qualidade - Inmetro since 1998, where he is currently the head of the Thermal Metrology Division - Diter.

Bibliographic Data

Teixeira, Renato Nunes
Development of high temperature comparison
artefacts for radiation thermometry / Renato Nunes
Teixeira; advisor: Alcir de Faro Orlando; co-advisor:
Graham Machin. - 2013.
120 f. : il. (color.) ; 30 cm
Tese (doutorado) - Pontifícia Universidade
Católica do Rio de Janeiro, Departamento de Engenharia
Mecânica, 2013.
Inclui bibliografia
1. Engenharia Mecânica - Teses. 2. Pontos-
fixos de alta temperatura. 3. Termometria de radiação. 4.
Artefatos de comparação. 5. Altas temperaturas. I.
Orlando, Alcir de Faro. II. Machin, Graham. III. Pontifícia
Universidade Católica do Rio de Janeiro. Departamento de
Engenharia Mecânica. IV. Título.




\section{Acknowledgements}

To my parents, for giving me opportunities to achieve this;

To my wife Iakyra and my daughter Nina, for all their support, care and love;

To the advisors Alcir and Graham, for their support, trust and stimulus;

To the professors from PUC-Rio, for the teaching and friendship;

To PUC-Rio for all the support, that made this thesis possible;

To Inmetro, for making this thesis possible to be developed;

To the post-graduation colleagues, for their friendship;

To all the colleagues from Inmetro/Diter, specially Ricardo, Mário and Elsenir for all their help;

To professor Roberto Avillez, for all his wise suggestions, support and patience;

To all the administrative staff of the Mechanical Engineering Department, for all their help;

To Dr. Ursula Kattner from NIST, for her collaboration in the simulation of the doped metal-carbon alloys. 


\section{Abstract}

Teixeira, Renato Nunes; Orlando, Alcir de Faro; Machin, Graham.

Development of High Temperature Comparison Artefacts for Radiation

Thermometry. Rio de Janeiro, 2013. 120p. Doctoral Thesis Departamento de Engenharia Mecânica, Pontifícia Universidade Católica do Rio de Janeiro.

High stability tungsten strip lamps are no longer suitable comparison artefacts for high temperature radiation thermometry, because they are fragile, have a small target size, are restricted in temperature range and are not blackbodies. This study developed proof-of-concept high performance comparison artefacts, which overcome the problems encountered when using such lamps in comparisons of the International Temperature Scale of 1990 (ITS90) among National Metrology Institutes (NMIs). This work demonstrated the concept of using high temperature fixed points (HTFPs) that have unknown temperatures and hence suitable as "blind" comparison artefacts. Four of these novel HTFPs were designed, constructed, filled and measured in the work described here. Initially $\mathrm{Co}-\mathrm{C}$ was chosen but due to robustness issues, $\mathrm{Ni}-\mathrm{C}$ was the selected the base eutectic alloy. The Ni-C cells were doped in two different concentrations with selected elements in a successful attempt to change the pure eutectic transition temperature by some tenths of degrees Celsius. The realization temperatures of eutectic cells determined at Inmetro were compared to the ones predicted by thermochemical simulation, using Thermo-Calc software and thermochemical property databases. In addition they were used to perform a "blind" comparison with the National Physical Laboratory (UK), which did not know beforehand what their temperatures were. Very good results were achieved (scale agreement and cell stability), demonstrating that doped cells are very suitable high temperature comparison artefacts for radiation thermometry.

\section{Keywords}

High Temperature Fixed-points; Radiation Thermometry; Comparison Artefacts; High Temperatures. 


\section{Resumo}

Teixeira, Renato Nunes; Orlando, Alcir de Faro; Machin, Graham. Desenvolvimento de Artefatos de Comparação de Alta Temperatura para Termometria de Radiação. Rio de Janeiro, 2013. 120p. Tese de Doutorado - Departamento de Engenharia Mecânica, Pontifícia Universidade Católica do Rio de Janeiro.

Lâmpadas de fita de tungstênio de alta estabilidade não são mais adequadas como artefatos de comparação para termometria de radiação de alta temperatura, por conta de serem frágeis, terem um tamanho de alvo pequeno, serem limitadas com relação a faixa de temperatura e não serem corpos negros. Este estudo desenvolveu protótipos de artefatos de comparação de alto desempenho, os quais podem superar os problemas existentes ao usar tais lâmpadas em comparações da Escala Internacional de Temperatura de 1990 (EIT-90) entre Institutos Nacionais de Metrologia (INMs). Este trabalho demonstrou o conceito de utilização de pontos fixos de alta temperatura (PFATs) que tenham temperaturas desconhecidas e assim sejam adequados como artefatos de comparações "às cegas". Quatro destes novos PFATs foram projetados, construídos, preenchidos e medidos no trabalho aqui descrito. Inicialmente Co-C foi escolhido, mas devido a problemas de robustez, a liga eutética base selecionada foi Ni-C. As células Ni-C foram dopadas em duas concentrações diferentes com elementos selecionados em uma tentativa bem sucedida de modificar temperatura de transição do eutético puro em alguns décimos de graus Celsius. As temperaturas de realização das células eutéticas determinadas no Inmetro foram comparadas com aquelas previstas por simulação termoquímica, usando o programa Thermo-Calc e bancos de dados de propriedades termoquímicas adequados. Além disso, elas foram utilizadas para realizar uma comparação "às cegas” com o National Physical Laboratory (NPL UK), o qual não sabia "a priori” quais eram essas temperaturas. Resultados muito bons foram alcançados (concordância das escalas e estabilidade das células), demonstrando que as células dopadas são artefatos de comparação de alta temperatura bem adequados para termometria de radiação.

\section{Palavras-chave}

Pontos-fixos de Alta Temperatura; Termometria de Radiação; Artefatos de Comparação; Altas Temperaturas. 


\section{Contents}

1 Introduction 14

$\begin{array}{ll}\text { 1.1. Background } & 14\end{array}$

1.2. Motivation for this research 19

1.3. Scope of the work 21

1.4. Structure of the thesis 23

2 Principles of temperature measurement 25

2.1. Temperature scales $\quad 27$

2.2. The International Temperature Scale of 1990 (ITS-90) 30

2.3. Temperature sensors 34

2.3.1. Contact sensors 34

$\begin{array}{ll}\text { 2.3.2. Non-contact temperature sensors } & 37\end{array}$

3 State of the art in radiation thermometry 39

3.1. Review of radiation thermometry 39

3.2. High temperature eutectic cells 41

3.3. Description of the standard pyrometer, the LP3 44

4. Thermodynamic modeling of multicomponent phase equilibria $\quad 49$

4.1. The CALPHAD method 49

4.1.1. Introduction 49

4.1.2. History 50

4.1.3. Scope of phase diagram calculations $\quad 51$

4.1.4. Thermodynamic descriptions and models 51

4.1.5. Continuous improvements $\quad 54$

4.1.6. Computer software and databases 55

4.2. Systems modeled 55

4.2.1. Cobalt-Carbon 56

4.2.2. Nickel-Carbon 58 
5 Experimental methods $\quad 60$

5.1. Design and construction of the cells 60

5.2. Choosing of the dopant for the eutectic cell 63

5.3. Melting point determination 65

5.4. Preliminary measurements with Co-C system 66

5.5. Definition of transition temperature in M-C fixed-points 69

5.6. Filling of high temperature fixed points 70

5.7. High temperature equipment used for this research 71

5.8. Experimental setup 73

5.8.1. Weighing balance Sartorius ME235S 73

5.8.2. Carbolite furnace model TZF 18/75/600 74

5.8.3. Carbolite furnace model TZF 12/75/600 76

5.8.4. Silver fixed point cell 77

5.9. Data reduction in the temperature determination 78

$\begin{array}{ll}\text { 5.10. Summary of the chapter } & 81\end{array}$

6 Results of $\mathrm{Ni}-\mathrm{C}$ and $\mathrm{Ni}-\mathrm{C}-\mathrm{Cu}$ eutectic cells 82

6.1. Ni-C reference cell (Ni-C \#6) 82

6.1.1. Experimental results 82

6.1.2. Simulation results 85

6.2. Ni-C-Cu 4168 ppm doped cell (Ni-C-Cu \#7) 85

6.2.1. Experimental results $\quad 85$

6.2.2. Simulation results $\quad 87$

6.3. Ni-C-Cu 7686 ppm doped cell (Ni-C-Cu \#8) 88

6.3.1. Experimental results 88

6.3.2. Simulation results $\quad 91$

6.4. Summary of Ni-C-Cu measurements 91

$\begin{array}{ll}\text { 6.5. Summary of the chapter } & 93\end{array}$

7 Results of Ni-C-Sn eutectic cells 94

7.1. Ni-C-Sn 828 ppm doped cell (Ni-C-Sn \#9) 94

$\begin{array}{ll}\text { 7.1.1. Experimental results } & 94\end{array}$ 
7.1.2. Simulation results

7.2. Ni-C-Sn 392 ppm doped cell (Ni-C-Sn \#10) 96

7.2.1. Experimental results 96

7.2.2. Simulation results 98

7.3. Summary of Ni-C-Sn measurements 98

7.4. Summary of the chapter 100

8 Results of a blind comparison with NPL using the Ni-C-Cu cells 101

8.1. Introduction 101

8.2. Measurements with the Ni-C-Cu \#7 (4168 ppm) cell 103

8.3. Measurements with the Ni-C-Cu \#8 (7686 ppm) cell 104

8.4. Furnace effects of the temperature realised for the Ni-C-Cu cells 105

8.5. Summary of the chapter 106

9 Uncertainty evaluation 107

9.1. Uncertainty in the determination of the temperature of phase transition of the metal-carbon eutectic cell 107

9.2. Uncertainty in the determination of the concentration of dopants in the metal carbon alloy

10 Conclusions and suggestions for future work 


\section{List of figures}

Figure 1: Defining fixed points of the ITS-90 and interpolating thermometers

Figure 2: Representation of a typical phase diagram of an alloy that forms a eutectic

Figure 3: Schematic diagram of the optical design of the LP3 45

Figure 4: Spectral responsivity curve for $650 \mathrm{~nm}$ interference filter $\quad 47$

Figure 5: Spectral responsivity curve for $900 \mathrm{~nm}$ interference filter $\quad 47$

Figure 6: Example of a binary phase diagram 50

Figure 7: A Thermo-Calc screen to select the elements 56

Figure 8: Phase diagram of the Co-C system 57

Figure 9: Phase diagram of the Ni-C system 58

Figure 10: Blackbody cell design used in this study - dimensions in millimeters $\quad 60$

Figure 11: Parts of the eutectic cell 62

Figure 12: Typical eutectic cell 62

Figure 13: Thermal Technologies Furnace 63

Figure 14: Example of the determination of the point of inflection of the melting curve of the $\mathrm{Ni}-\mathrm{C}$ eutectic 66

Figure 15: Realization of Co-C (left) and Co-C-Cu (right) eutectics 67

Figure 16: Blackbody cavities - (a) Old model (b) New model 67

Figure 17: Typical realization curve of the Co-C eutectic in the carbolite 3-zone furnace

Figure 18: Heating and cooling program for Thermal Technologies furnace $\quad 71$

Figure 19: Measurement setup at Pyrometry Laboratory 72

Figure 20: Sartorius ME235S Balance $\quad 74$

Figure 21: Heating/cooling program of the Carbolite TZF18 furnace $\quad 75$

Figure 22: Assembly of the eutectic cell inside Carbolite TZF 18 furnace 76

Figure 23: Assembly of the silver cell inside the furnace 77

Figure 24: Original (left) and modified (right) silver blackbody cavity $\quad 78$ 
Figure 25: Typical freezing plateau of the silver fixed point cell

Figure 26: Measurement data as processed by the Scilab/Gnuplot software

Figure 27: Realization of the Ni-C \#6 eutectic cell 83

Figure 28: Realization of the Ni-C-Cu \#7 eutectic cell 86

Figure 29: Realization of the Ni-C-Cu \#8 eutectic cell 89

Figure 30: LP3 pyrometer equipped with thermal radiation shield $\quad 90$

Figure 31: Comparison of realization curves of $\mathrm{Ni}-\mathrm{C}$ and $\mathrm{Ni}-\mathrm{C}-\mathrm{Cu}$ eutectic cells 92

Figure 32: Effect of addition of copper in the Ni-C eutectic alloy 93

Figure 33: Realization of the Ni-C-Sn \#9 eutectic cell 95

Figure 34: Realization of the Ni-C-Sn \#10 eutectic cell 97

Figure 35: Comparison of realization curves of $\mathrm{Ni}-\mathrm{C}$ and Ni-C-Sn eutectic cells 99

Figure 36: Effect of addition of tin in the Ni-C eutectic alloy 99

Figure 37: Effect of the furnace on the melting temperature of $\mathrm{Ni}-\mathrm{C}-\mathrm{Cu} \# 7$

Figure 38: Different furnace effects on the realized temperature of the $\mathrm{Ni}-\mathrm{C}-\mathrm{Cu}$ cells 


\section{List of tables}

Table 1: Base units of the International System of Units (SI)

Table 2: Metal-carbon and metal carbide-carbon eutectics and their approximate fixed-point temperature

Table 3: Defining fixed-points of the ITS-90 32

Table 4: Melting temperature of some metal-carbon eutectic alloys 43

Table 5: Summary of temperatures calculated for Co-C/Co-C-Cu 57

Table 6: Summary of temperatures calculated for $\mathrm{Ni}-\mathrm{C} / \mathrm{Ni}-\mathrm{C}-\mathrm{Cu} \quad 59$

Table 7: Summary of temperatures calculated for Ni-C/Ni-C-Sn 59

Table 8: Thermophysical properties of 1940PT graphite 61

Table 9: Physical properties of $\mathrm{Co}, \mathrm{Ni}$ and selected dopants 69

Table 10: Ni-C \#6 realisations 84

Table 11: Ni-C melting temperature 85

Table 12: Ni-C-Cu \#7 realisations 87

Table 13: Simulated and Measured Temperatures for

$\mathrm{Ni}-\mathrm{C}-\mathrm{Cu} 4168 \mathrm{ppm} \quad 88$

Table 14: Ni-C-Cu \#8 realisations 89

Table 15: Simulated and Measured Temperatures for $\mathrm{Ni}-\mathrm{C}-\mathrm{Cu} 7686$ ppm 91

Table 16: Results for the Ni-C-Sn 828 ppm eutectic cell 95

Table 17: Simulated and Measured Temperatures for Ni-C-Sn 828 ppm 96

Table 18: Results of the realization of Ni-C-Sn \#10 97

Table 19: Simulated and Measured Temperatures for Ni-C-Sn 392 ppm 98

Table 20: Summary of temperature measurements of Inmetro and NPL for the Ni-C-Cu \#7 cell 103

Table 21: Summary of temperature measurements of Inmetro and NPL for Ni-C-Cu \#8 105

Table 22: Uncertainty budget of the temperature determination 109 